[Report]

\title{
The Effects of Thigh Corset with Side Bars Suspension in a Subject with Transtibial Amputation: A Biomechanical Investigation
}

\author{
Mohammad HadAdi ${ }^{1}$, Kamiar GHOSEIRI ${ }^{2 *}$ and Roshanak VAMEGHI ${ }^{3}$ \\ ${ }^{1}$ Center for Human Movement Science Research, Shiraz University of Medical Sciences Shiraz 7194733669, Iran \\ 2 Department of Orthotics and Prosthetics, University of Social Welfare and Rehabilitation Sciences, Tehran \\ 1985713834, Iran \\ ${ }^{3}$ Pediatric Neurorehabilitation Research Center, University of Social Welfare and Rehabilitation Sciences, Tehran \\ 1985713834, Iran
}

\begin{abstract}
This study aims to investigate some biomechanical effects of a thigh corset with side bars (TC-SB) on the gait of a transtibial amputee. During two test conditions of with/without TC-SB, the angles of prosthetic lower limb joints, stride time, stance time and maximum vertical ground reaction force were evaluated. Only the angle of hip joint at initial contact and its maximum flexion at swing phase had significant changes $(P<0.05)$. This may suggest the amputee has used a compensatory mechanism to overcome the additional weight of the TC-SB suspension. It seems that the participated amputee has no need for this auxiliary suspension.
\end{abstract}

Keywords : transtibial amputee, suspension, thigh corset with side bars, biomechanics.

(Received May 20, 2013, accepted October 25, 2013)

\section{Introduction}

Based on previous reports, transtibial amputation accounts for almost $50 \%$ of all new amputations $[1,2]$. Comfort and mobility are the two most important issues for using prosthesis that respectively are affected by proper fit and appropriate selection of suspension systems. Suspension systems describe the way that prosthesis attaches to the residual limb. Appropriate selection of the suspension system for transtibial prosthesis is dependent on length, shape, volume and joint stability of the residual limb [3, 4]. In addition, amputee's expectations about durability, appearance, donning and activity level, also his/her dexterity and previous experience of suspension systems should be considered [4].
Historically there were two primary prosthetic designs for transtibial amputees: the traditional design that dates back to 1696 , and the patellar tendon bearing (PTB) design [5]. The traditional design had a thigh corset with side bars (TC-SB) and an open-ended wooden socket [5]. It was known as "conventional below knee prosthesis" until the introduction of the PTB prosthesis [6]. One modification to PTB was supracondylar suprapatellar design that was introduced in 1964 and named PTS (Prosthèse Tibiale Supracondylienne) [6]. PTS was prescribed primarily in transtibial amputees with short residual limb and knee recurvatum [4]. This design has a great interface with the residual limb and a bar above the patella that limits knee extension [4]. The PTS socket lets less pistoning movement in the cylindrical residual limb versus conical ones [3].

*Corresponding Author: Kamiar GHoserri, Orthotics and Prosthetics Department, University of Social Welfare and Rehabilitation Sciences, Tehran 1985713834, Iran. Tel: (+9821) 22180049, Fax: (+9821) 22180109, Email: kamiar_g@yahoo.com 
Rubin et al reported that due to inherent self-suspension design, the PTS socket had no need for auxiliary suspension [7].

The TC-SB is an auxiliary suspension consisting of a leather or thermoplastic thigh corset and two metal side bars that connect to the socket by bilateral hinges. The thigh corset should be fastened around the distal two thirds of thigh [8]. The literature suggested that its application should be limited to amputees with fragile skin, unstable knee joint, insufficient residual limb length, insufficient patellar tendon bearing, distal residual limb pain, heavy duty jobs and mental retardation $[4,7-12]$.

TC-SB has been mentioned as the most cumbersome transtibial suspension [4]. Thigh muscle atrophy, increasing limb pistoning, noncosmetic appearance, and higher weight are stated as its major disadvantages [4, $5,13]$. Despite the great disadvantages of the TC-SB suspension, its application has continued until now. At present in Iran, its popularity and prescription seems to be even more than the global rate. Many amputees are not proper candidates to use this auxiliary suspension, especially those with PTS sockets, but due to psychological issues or previous experience may prefer to continue its use. Based on the author's knowledge, there is no study in the literature to investigate the effects of TC-SB suspension on kinematic and kinetic parameters during gait of the amputees. This case study aims to investigate the efficiency of TC-SB suspension in an evaluated subject based on some kinematic and kinetic parameters.

\section{Methods}

\section{Subject}

A thirty one year old man (179 cm height, $66 \mathrm{~kg}$ weight) with left transtibial amputation secondary to an agricultural trauma. The subject had 16 years experience of prosthesis wearing using PTS socket with bilateral hinge TC-SB auxiliary suspension. His residual limb had $7 \mathrm{~cm}$ length and was free from blisters, pain, sores, and swelling.

\section{Procedure}

After description of the study aims, a written informed consent was obtained from the subject. The Ethics Com- mittee of the University of Social Welfare and Rehabilitation Sciences approved all aspects of the study.

After full evaluation of the subject, an endoskeletal transtibial prosthesis was fabricated by an experienced certified and licensed prosthetist at the Iranian Red Crescent Rehabilitation Center. The fabricated prosthesis was evaluated by two other prosthetists to ensure its optimal fit, alignment and function. The prosthesis consisted of a PTS socket, pylon, single axis foot (Otto Bock, Germany) and TC-SB suspension. The total weight of the prosthesis was $2.86 \mathrm{~kg}$; TC-SB suspension accounted for approximately $31 \%$ of it $(0.89 \mathrm{~kg})$.

The biomechanical investigation of the current study includes analysis of some kinematic parameters and a kinetic parameter of the amputated side. The kinematic data of gait were collected by Vicon motion analysis system (Oxford Metrics, Oxford, UK) with six infrared cameras and passive retroreflective markers (20 $\mathrm{mm}$ diameter). The kinetic data was measured using two Kistler force platforms $(40 \times 60 \mathrm{~cm})($ Kistler Instruments Corp, NY, USA), which were embedded in the middle of the walkway. For kinematic analyses, the stride time, stance time, joint angles (hip, knee, ankle) at initial contact and preswing as well as the maximum hip and knee flexion at swing phase were evaluated in the sagittal plane. The maximum vertical ground reaction force (Max.VGRF) at loading response and terminal stance were measured as kinetic parameters. Selection of parameters was based on a previous study that had determined the appropriateness of these parameters in gait analysis of lower limb amputees [14]. The subject was instructed to don the prosthesis in two separate conditions with/without using TC-SB suspension. The subject walked at self-selected speed $(\sim 0.97 \mathrm{~m} / \mathrm{s})$ on an indoor $3 \mathrm{~m}$ level walkway 3 times for each test condition [14]. The data were sampled at $100 \mathrm{~Hz}$. The signals were filtered and smoothed by 4th-order low pass Butterworth technique with cut-off frequency of $6 \mathrm{~Hz}$. The measures of the 2 test conditions were compared with each other using paired $t$-test. All statistical analyses were carried out using the SPSS software version 11 (SPSS Inc, USA), with the significance level set at 0.05 . 


\section{Results}

The results of the study are summarized in Table 1 . At initial contact, there was a significant difference $(P<0.05)$ in hip angle while no significant differences were found in knee and ankle angles. Comparison of all joint angles in 2 test conditions revealed no statistical differences at preswing. The results showed that maximum joint flexion in the swing phase was significant solely in the hip joint $(P<0.05)$. The thigh corset with side bars suspension neither had significant effect on stride time or stance time, nor on Max.VGRF at loading response and terminal stance (Table 1).

Figure 1 shows a comparison of the hip, knee and ankle joint angles in 2 test conditions with respect to swing and stance phases of gait.

Table 1. Comparison of biomechanical parameters in 2 test conditions

\begin{tabular}{|c|c|c|c|c|c|}
\hline Parameters & Test Condition & Mean \pm S.D. & Mean of Differences & $t$-statistics & $P$ \\
\hline \multirow{2}{*}{ Hip Angle at IC (d) } & TCSB & $26.73 \pm 0.42$ & \multirow{2}{*}{2.66} & \multirow{2}{*}{7.64} & \multirow{2}{*}{$0.01 *$} \\
\hline & WTCSB & $24.06 \pm 1.00$ & & & \\
\hline \multirow{2}{*}{ Hip Angle at PS (d) } & TCSB & $-10.03 \pm 2.22$ & \multirow{2}{*}{-2.24} & \multirow{2}{*}{-0.79} & \multirow{2}{*}{0.50} \\
\hline & WTCSB & $-7.79 \pm 3.04$ & & & \\
\hline \multirow{2}{*}{ Max. Hip Flexion at Swing (d) } & TCSB & $29.03 \pm 0.33$ & \multirow{2}{*}{2.74} & \multirow{2}{*}{8.85} & \multirow{2}{*}{$0.01 *$} \\
\hline & WTCSB & $26.28 \pm 0.67$ & & & \\
\hline \multirow{2}{*}{ Knee Angle at IC (d) } & TCSB & $9.17 \pm 0.57$ & \multirow{2}{*}{2.60} & \multirow{2}{*}{3.76} & \multirow{2}{*}{0.06} \\
\hline & WTCSB & $6.57 \pm 0.62$ & & & \\
\hline \multirow{2}{*}{ Knee Angle at PS (d) } & TCSB & $30.24 \pm 2.24$ & \multirow{2}{*}{-2.63} & \multirow{2}{*}{-1.42} & \multirow{2}{*}{0.29} \\
\hline & WTCSB & $32.88 \pm 2.98$ & & & \\
\hline \multirow{2}{*}{ Max. Knee Flexion at Swing (d) } & TCSB & $69.39 \pm 2.16$ & \multirow{2}{*}{-0.38} & \multirow{2}{*}{-0.12} & \multirow{2}{*}{0.91} \\
\hline & WTCSB & $69.77 \pm 3.29$ & & & \\
\hline \multirow{2}{*}{ Ankle Angle at IC (d) } & TCSB & $4.82 \pm 0.72$ & \multirow{2}{*}{1.32} & \multirow{2}{*}{0.987} & \multirow{2}{*}{0.42} \\
\hline & WTCSB & $3.50 \pm 1.59$ & & & \\
\hline \multirow{2}{*}{ Ankle Angle at PS (d) } & TCSB & $-5.61 \pm 0.57$ & \multirow{2}{*}{1.16} & \multirow{2}{*}{0.92} & \multirow{2}{*}{0.45} \\
\hline & WTCSB & $-6.78 \pm 1.86$ & & & \\
\hline \multirow[t]{2}{*}{ Max. VGRF at LR (N) } & TCSB & $666.74 \pm 16.59$ & \multirow{2}{*}{7.91} & 120 & 02 \\
\hline & WTCSB & $658.82 \pm 24.63$ & & 1.39 & 0.23 \\
\hline Max. VGRF at TS (N) & TCSB & $678.51 \pm 13.93$ & -1037 & -104 & 012 \\
\hline & WTCSB & $688.89 \pm 10.37$ & & & \\
\hline Stride Time (s) & TCSB & $1.42 \pm 0.02$ & 002 & 232 & 025 \\
\hline & WTCSB & $1.46 \pm 0.00$ & 0.03 & 2.53 & $0.2 \mathrm{~J}$ \\
\hline Stance Time (c) & TCSB & $0.91 \pm 0.03$ & ( 000 ? & 014 & 0.0 \\
\hline stance inme (s) & WTCSB & $0.91 \pm 0.01$ & 0.002 & 0.14 & 0.89 \\
\hline
\end{tabular}

VGRF: vertical ground reaction force, IC: initial contact, PS: preswing, LR: loading response, TS: terminal stance, TCSB: thigh corset with side bars, WTCSB: without thigh corset and side bars, d: degree, N: newton, s: second. *Significant differences are set at $P<0.05$ 

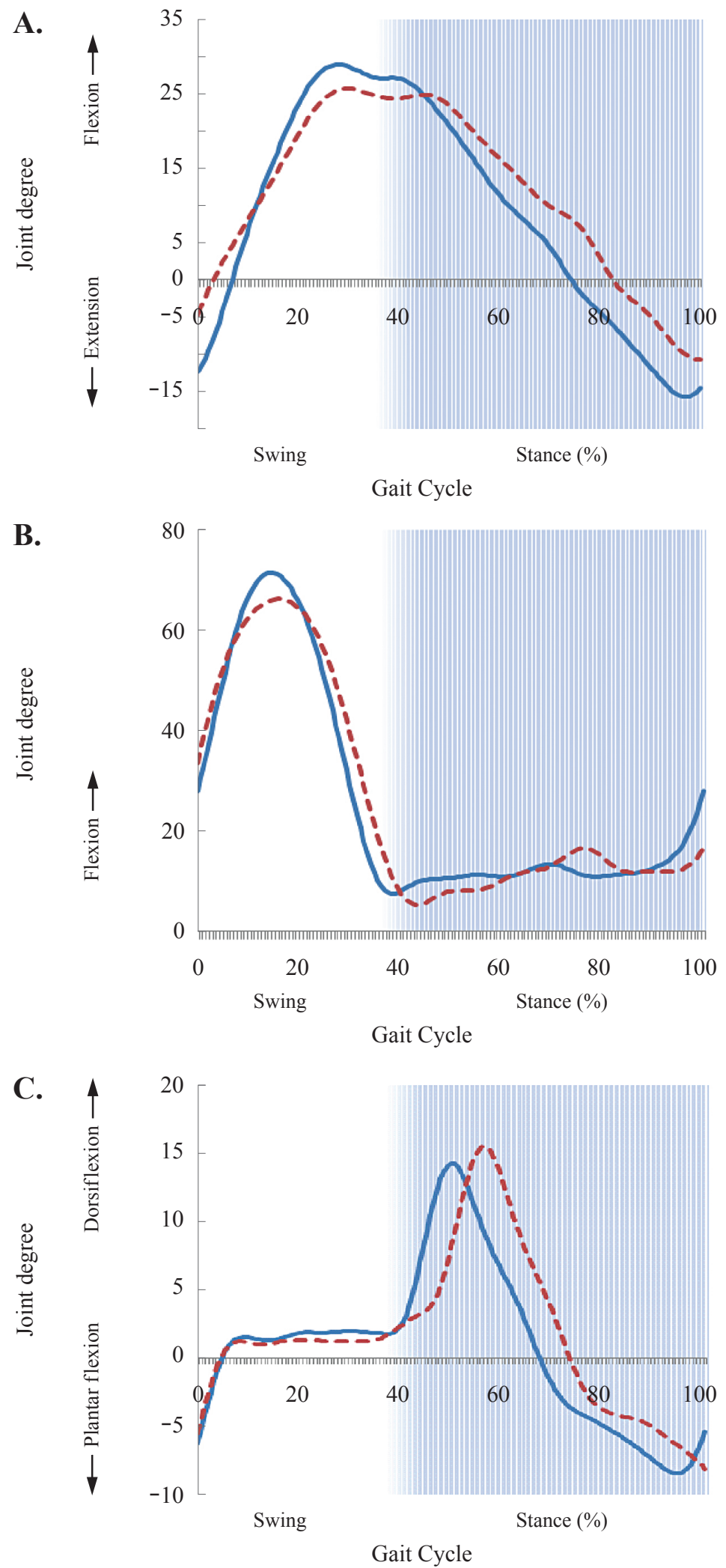

Fig. 1. Joint angles during gait cycle. A: hip joint, B: knee joint, C: ankle joint, - : with TC-SB, - - : without TC-SB. 


\section{Discussion}

The biomechanical characteristics of the TC-SB suspension have received a limited deal of attention in the literature. Although the TC-SB suspension was the most prescribed suspension for transtibial prostheses until 1958, its application has decreased greatly nowadays [8]. Satisfied experienced amputees with TC-SB suspension due to their fear of successful prosthetic use prefer no change in their suspension and are psychologically dependent on it to keep their current level of activity $[3,11]$.

In the present study during 2 test conditions of with/ without the TC-SB suspension, kinematic evaluations were conducted by measuring hip, knee and ankle joint angles. These angles were evaluated at initial contact, preswing and swing phases. In the swing phase, the maximum hip and knee flexion angles were studied to determine the effect of the TC-SB suspension on foot clearance. Considering the passive structure of the prosthetic ankle foot complex, no swing phase evaluation was conducted for ankle joint.

The application of TC-SB suspension at initial contact significantly increased the hip joint angle, but it had no significant effect on the angles of knee or ankle joints. At the preswing phase the evaluation of 3 joint angles revealed no significant change. The maximum joint flexion angle showed significant change solely in the hip joint, with higher values pertaining to TC-SB suspension use.

It seems that to overcome the additional weight of the TC-SB suspension the amputee increased the hip joint flexion of the prosthetic side, which may provide better foot clearance and limb propulsion [15]. More hip joint flexion may be associated with more energy expenditure and muscle fatigue [16, 17]. No significant change in knee joint angle in 2 test conditions may be due to inherent control of the amputee over the prosthesis that let him use previous motor patterns while tolerating some changes in prosthetic alignment [18]. Selles et al based on a mathematical model of transtibial prosthesis, showed that mass perturbations of the prosthesis could affect kinematic of amputee gait [19]. Referring to their findings, it could be suggested that TC-SB suspension may play an important role in changing the angle of hip joint by changing the mass distribution of the prosthesis [19].

The kinetic evaluation during 2 test conditions of with/without the TC-SB suspension was conducted by measuring the Max.VGRF. Although the TC-SB suspension increased the prosthesis weight, the results of the Max.VGRF showed no significant difference between the 2 test conditions. This finding may suggest that with TC-SB suspension the amputee used a compensatory mechanism [20] to shift some of his weight to the contralateral intact side [21].

The majority of studied biomechanical parameters in the current study showed no significant difference in the 2 test conditions. Based on the biomechanical data from the sagittal plane analyses, it suggested that prescription of TC-SB suspension may not be necessary in this patient.

It is worth noting that the present study has with some limitations. It was an immediate effect biomechanical investigation of TC-SB suspension. The authors conducted the kinematic investigation based on coordinate system only in the sagittal plane and just for the amputated side. Further biomechanical investigations, especially in mediolateral plane and also for the intact side could provide better insight into the effects of TC-SB suspension and amputee-used compensatory mechanisms.

\section{Conclusion}

Study findings suggest that prescription of TC-SB suspension may not be necessary for the participated amputee. In this subject, thigh corset with side bars suspension increased prosthesis weight by $31 \%$, which might affect the prosthetic performance. It also seems that the amputee used some compensatory mechanisms to overcome this additional weight, which needs further investigation.

\section{Acknowledgements}

The authors would like to acknowledge the financial support of the Student's Committee in University of Social Welfare and Rehabilitation Sciences. 


\section{References}

1. Kay HW \& Newman JD (1975): Relative medicine of new amputations: Statistical comparisons of 6,000 new amputees. Orthot Prosthet 29: 3-16

2. National Amputee Statistical Database (NASDAB) (2009): Information Services Division NHS Scotland (2009): Limbless Statistics. The amputee statistical database for the United Kingdom 2006/07. Edinburgh (UK) p 3, http://www.limbless-statistics.org/

3. Wirta RW, Golbranson FL, Mason R \& Calvo K (1990): Analysis of below-knee suspension systems: effect on gait. J Rehabil Res Dev 27: 385-396

4. Kapp S (1999): Suspension systems for prostheses. Clin Orthop Relat Res 361: 55-62

5. Silver-Thorn MB (2002): Design of artificial limbs for lower extremity amputees. In: Standard Biomedical Engineering and Design Handbook. (Kutz Med). The McGraw-Hill Professional, Inc. New York pp 9-10

6. Pritham CH (1979): Suspension of the below-knee prosthesis: An overview. Orthot Prosthet 33: 1-19

7. Rubin G, Nitschke RO \& Gardner HF (1970): The supracondylar-suprapatellar PTB prosthesis. Bull Prosthet Res 10 (14): 102-106

8. Shem KL, Breakey JW \& Werner PC (1998): Pressures at the residual limb-socket interface in transtibial amputees with thigh lacer-slide joints. J Prosthet Orthot 10: $51-55$

9. Uustal H \& Baerga E (2004): Prosthetics and Orthotics. NCBI: Physical Medicine and Rehabilitation Board Review. (Cuccurullo $\mathrm{S}$ ed). Demos Medical Publishing Inc, New York pp 463-504

10. Radcliffe CW (1962): The biomechanics of belowknee prostheses in normal, level, bipedal walking. Artif Limbs 6: 16-24

11. Foort J (1965): The patellar-tendon-bearing prosthesis for below-knee amputees, a review of technique and criteria. Artif Limbs 9: 4-13
12. Breakey JW (2000): Transtibial Prostheses. In: Orthotics and Prosthetics in Rehabilitation. (Lusardi MM, Jorge M \& Nielsen CC eds), The Saunders Elsevier Inc, St. Louis pp 645-648

13. Weiss J, Middleton L, Gonzalez E \& Lovelace RE (1983): The thigh corset: its effects on the quadriceps muscle and its role in prosthetic suspension. Orthotics and Prosthetics 37(3): 58-62

14. Sagawa YJr, Turcot K, Armand S, Thevenon A, Vuillerme N \& Watelain E (2011): Biomechanics and physiological parameters during gait in lower-limb amputees: a systematic review. Gait Posture 33: 511-526

15. Hekmatfard M, Farahmand F \& Ebrahimi I (2013): Effects of prosthetic mass distribution on the spatiotemporal characteristics and knee kinematics of transfemoral amputee locomotion. Gait Posture 37: 78-81

16. Browning RC, Modica JR, Kram R \& Goswami A (2007): The effects of adding mass to the legs on the energetics and biomechanics of walking. Med Sci Sports Exerc 39: 515-525

17. Martin PE (1985): Mechanical and physiological responses to lower extremity loading during running. Med Sci Sports Exerc 17: 427-433

18. Zahedi MS, Spence WD, Solomonidis SE \& Paul JP (1986): Alignment of lower-limb prostheses. J Rehabil Res Dev 23: 2-19

19. Selles R, Bussmann J, Van Soest AJ \& Stam H (2004): The effect of prosthetic mass properties on the gait of transtibial amputees-a mathematical model. Disabil Rehabil 26: 694-704

20. Tokuno CD, Sanderson DJ, Inglis JT \& Chua R (2003): Postural and movement adaptations by individuals with a unilateral below-knee amputation during gait initiation. Gait Posture 18: 158-169

21. Silverman AK, Fey NP, Portillo A, Walden JG, Bosker G \& Neptune RR (2008): Compensatory mechanisms in below-knee amputee gait in response to increasing steady-state walking speeds. Gait Posture 28: 602-609 
下腿切断者における側方支柱付き大腿コルセットによる懸垂の効果：生体力学的研究

モハマッド ハダディ ${ }^{1}$, カミアル ゴセイリイ ${ }^{2}$, ロシャナック ヴァメギ

1 シラズ医療科学大学 人間行動科学研究センター

2 社会福祉社会復帰科学大学 矯正・補緅学科

3 社会福祉社会復帰科学大学 小巟科学神経復帰研究センター

要旨：本研究は側方支柱付き大腿コルセット(TC-SB) が下腿切断者の歩行に及ぼす生体力学的影響を調べる ことを目的とする。TC-SBがある場合とない場合の 2 条件において, 義足側下肢の関節角度, 重複歩時間, 立脚時間, 垂直床反力を計測した。初期接地での股関節角度と遊脚相の股関節最大屈曲角度に, 有意差 $(P<0.05)$ を認めた。こ れは下腿切断者がTC-SB懸垂の重量が加わることに打ち勝つために, 代償的メカニズムを利用していることを示唆 する．被験者の下腿切断者には, この補助的懸垂が必要でないと考えられる.

キーワード：下腿切断, 懸垂, 側方支柱付大腿コルセット, 生体力学.

J UOEH (産業医科大学雑誌) 35(4)：259-265(2013) 